\title{
Approaches to Observe Anthropogenic Aerosol-Cloud Interactions
}

\author{
Johannes Quaas ${ }^{1}$
}

Published online: 11 November 2015

(C) The Author(s) 2015. This article is published with open access at Springerlink.com

\begin{abstract}
Anthropogenic aerosol particles exert an - quantitatively very uncertain-effective radiative forcing due to aerosol-cloud interactions via an immediate altering of cloud albedo on the one hand and via rapid adjustments by alteration of cloud processes and by changes in thermodynamic profiles on the other hand. Large variability in cloud cover and properties and the therefore low signal-to-noise ratio for aerosolinduced perturbations hamper the identification of effects in observations. Six approaches are discussed as a means to isolate the impact of anthropogenic aerosol on clouds from natural cloud variability to estimate or constrain the effective forcing. These are (i) intentional cloud modification, (ii) ship tracks, (iii) differences between the hemispheres, (iv) trace gases, (v) weekly cycles and (vi) trends. Ship track analysis is recommendable for detailed process understanding, and the analysis of weekly cycles and long-term trends is most promising to derive estimates or constraints on the effective radiative forcing.
\end{abstract}

Keywords Aerosol-cloud interactions · Radiative forcing · Observational constraint $\cdot$ Anthropogenic emissions $\cdot$ Cloud modification - Ship tracks · Hemispherical contrast · Weekly cycles $\cdot$ Pollution trends

\section{Introduction}

The radiative forcing anthropogenic aerosol particles exert when they serve as cloud condensation nuclei (CCNs) and

This article is part of the Topical Collection on Climate Feedbacks

Johannes Quaas

johannes.quaas@uni-leipzig.de

1 Institute for Meteorology, Universität Leipzig, Stephanstr. 3, 04103 Leipzig, Germany ice nucleating particles (INPs) and thus modify cloud properties: the forcing due to aerosol-cloud interactions is the most uncertain one among the forcings of anthropogenic climate change [1]. An enhanced CCN concentration leads to larger concentrations of cloud droplets in liquid water clouds. It also leads to larger concentrations of ice crystals in ice clouds when they form by homogeneous freezing of haze particles in suitable conditions [2]. Even for constant cloud water path, when the average particle sizes are reduced, this enhances the overall scattering cross section and cloud albedo is larger than without the additional anthropogenic aerosol [3]. In case of heterogeneous freezing in ice clouds, in contrast, additional INP may lead to fewer, larger ice crystals, reducing cirrus albedo [4].

The shift in particle size spectra impacts cloud microphysical and dynamical processes. Growth of cloud particles via collision and coalescence depends on the relative velocity of the particles in an air parcel, mostly determined by the fall velocity. Since fall velocity is a non-linear function of particle size, a change in size spectra alters this process and, hence, the precipitation formation. It has been postulated that the delay in precipitation formation may lead to larger cloud cover [5], but this is disputed [6-9]. Cloud depth and cloud water path are expected to increase [10]. Since fallout of water from the liquid phase is reduced, in deep convective clouds, the anvil created from detrainment might become thicker in a polluted environment [11]. Other processes may lead to decreases in cloud radiative effects. For liquid water clouds, smaller particles more readily evaporate due to the larger surface-tovolume ratio, so an increase in CCN may also lead to less, thinner clouds [6]. Also, the cloud-top entrainment rate is, besides its dependency on the thermodynamic profiles, a function of precipitation rate for shallow, stratiform clouds [12]. Depending on the humidity above the cloud layer, a reduction in precipitation may thus lead to more entrainment of dry air 
and, subsequently, a reduction in cloudiness [13] and liquid water path [14]. For ice- and mixed-phase clouds, INP might lead to more rapid glaciation of a cloud and shorter lifetime [15]. A phase change from liquid to ice may be favoured by additional INP, leading to smaller albedo [16, 17].

Absorption of sunlight and subsequent heating of the atmosphere might lead to more or less cloudiness, depending on the altitude of the aerosol relative to the cloud [18-21]. The various processes interact in a dynamical environment, often leading to a buffering of the initial perturbation $[9,22]$.

The concept of the effective radiative forcing $[23,24]$ considers the radiative forcing itself that is introduced virtually immediately with an altered aerosol concentration due to the change in cloud albedo, with all other state variables unchanged, but also fast cloud adjustments that occur on short time scales, namely faster than changes in the large-scale circulation or surface temperatures [25-27]. The effects described in the first paragraph above constitute the radiative forcing due to aerosol-cloud interactions [1] (formerly known as first aerosol indirect effects). The effects described in the second paragraph refer to the adjustments to the aerosol-cloud interactions. The third paragraph finally introduced the adjustments to the aerosol-radiation interactions (formerly known as semi-direct effect). Besides these cloud microphysical and microdynamical adjustments, also the surface temperatures on continents and, subsequently, the thermodynamic profiles react, leading to further adjustments $[20,28]$.

There is a sound theoretical basis for several of the concepts of possible effects of anthropogenic aerosols on clouds and radiation described above at the level of individual microphysical processes. The relevant relationships, e.g. between cloud droplet concentration and cloud albedo, have been observed from aircraft [29-31]. Statistical relationships between aerosol and cloud or radiation quantities as retrieved from satellite data support the expected sensitivities of cloud albedo with respect to aerosol perturbations. These relationships have been useful to constrain processes of aerosol-cloud interactions in climate models [32-37] to the degree of yielding a radiative forcing estimate or constraint [38-40]. However, these kinds of statistics themselves do not allow to infer conclusions about anthropogenic perturbations. In the context of this paper, the full anthropogenic perturbation with respect to a natural-only reference is generally used to avoid the definition of the small anthropogenic perturbations even of the 1850 aerosol concentrations [41, 42].

The fact that the uncertainty in radiative forcing is so large is, thus, not primarily due to a lack in process understanding or in process observation. It rather is due to the fact that (a) the anthropogenic contribution to the perturbation of clouds is uncertain and (b) the overall effect, involving all interacting processes, quantitatively is highly uncertain.

The aim of this review is to identify and discuss approaches by which the perturbation of clouds and, subsequently, radiation by anthropogenic aerosols can be observed in order to either directly quantify the radiative forcing or constrain it as simulated by climate models. I identified six methods that have been proposed to this end:

1. Intentional cloud modification: In field experiments and also at local scales semi-operationally, clouds have been seeded artificially with aerosol in weather modification or climate engineering experiments.

2. Ship tracks are evident manifestations of an anthropogenic perturbation of clouds in the marine boundary layer.

3. Hemispheric contrast: Since anthropogenic emissions mostly take place in the Northern Hemisphere, a difference in cloud and radiation properties might be indicative of the anthropogenic perturbation.

4. Trace gases: While it is difficult to clearly distinguish anthropogenic from natural aerosol in measurements, some trace gases such as carbon monoxide can clearly be linked to combustion. Such tracers may mark air masses that are polluted and allow distinction from unperturbed ones. A related approach is to use chemistry transport models to identify anthropogenically influenced air masses.

5. Weekly cycles: Seven-day rhythms are highly unlikely due to natural variability and, thus, allow for a clear attribution to anthropogenic perturbations, if they can be identified with certainty.

6. Trends: There are long-term trends in anthropogenic aerosol emissions. To the extent that consistent cloud and radiation trends are observed, these may be attributed to the emission trends.

In the following, an overview is given about the state of the art and applicability of each of these six approaches.

\section{Intentional Cloud Modification by Aerosol}

Since the 1940s, experimental studies have been conducted aiming at weather modification. The principal aim of these was to (i) reduce hail, (ii) reduce fog and, most prominently, (iii) enhance rainfall by (a) seeding mixed-phase clouds with ice nucleating particles in an attempt to exploit the BergeronFindeisen effect to produce precipitation [43], (b) seeding supercooled liquid clouds in an attempt to increase buoyancy exploiting the latent heat of freezing [44] or (c) seeding liquid water clouds with giant $\mathrm{CCN}$ to circumvent delays in the collision-coalescence process [45-47].

Despite very large efforts, however, results are inconclusive [48]. Even when exploiting a land-sea contrast and orography and, thus, a forced repetitive condition for precipitation, as done in long-term Israeli experiments, no clear conclusions could be drawn [49]. A recent aircraft experiment in seeding 
marine stratocumulus with large aerosol particles was able to demonstrate shifts in microphysical characteristics [50] but did not proceed to study cloud albedo nor were they able to assess cloud modifications at a large scale beyond the selected individual ship tracks. In a climate engineering field experiment, a smoke generator onboard a ship below a stratocumulus deck off the North American West coast was used to artificially create $\mathrm{CCN}$. The zigzag track pattern was identified as a bright line in satellite imagery, and aircraft in situ observations allowed to document the cloud microphysical differences from the background [51]. However, only for a few cases was the detection possible.

Intentional cloud modification studies are potentially useful for an improved process understanding [52, 53]. However, they were not suitable for a constraint of the aerosol forcing due to their limited extent and the differences between the intentional and inadvertent emission of aerosols in terms of aerosol types, mixing state and spatiotemporal distributions.

\section{Ship Tracks}

Ship tracks are bright lines detectable from satellites in marine boundary layer clouds [54] in suitable conditions [55, 56]. These lines are attributed to the emission of suitable $\mathrm{CCN}$ by ship exhaust [57] that alters cloud droplet concentrations and, subsequently, cloud albedo [58]. They may be particularly visible since the surrounding area tends to become less bright due to induced boundary layer dynamics [59]. In turn, the effect may become very large in cases where a transition between open and closed cellular structure of stratocumulus clouds may be triggered $[60,61]$. Also in simulations with general circulation models, the global forcing attributable to ship emissions can yield, depending on the assumptions and large forcing estimates [62, 63].

However, the actual lines only account for 0.04 of the global area [64] and thus exert a very small radiative forcing on a global scale of estimated about $-0.5 \times$ $10^{-3} \mathrm{Wm}^{-2}$ [65]. A substantial diurnal cycle demonstrated from geostationary satellite data, with a maximum at the time of overpass of the polar-orbiting satellite from which this forcing was estimated, even suggests a smaller effect [66]. The effect of ship pollution beyond the narrow tracks is not distinguishable with statistical significance compared to the regions upwind the shipping routes [67]. This is due to the dilution of the aerosol that does spread around the ship track on the one hand and due to the large natural variability of clouds on the other hand $[63,68]$.

Nevertheless, ship tracks have proven very useful to identify and assess processes relevant for aerosol-cloud interactions [69-71], providing, for example, evidence for a shift in response between liquid- and mixed-phase clouds [72•]. The analysis of ship tracks showed that the response of cloud properties and cloud albedo depends on the cloud regime and differs between coupled and uncoupled boundary layers [73] and open and closed cells [74]. In summary, ship tracks have proven to provide a good environment to examine processes of aerosol-cloud interactions but are not useful to constrain the aerosol effective forcing at large scales.

While contrails from aircraft exhaust are also clear manifestations of an anthropogenic perturbation of cloudiness [75, 76], much of the perturbation is due to humidity perturbation rather than aerosol perturbations [77]. Contrails are, thus, not as suitable to assess aerosol-cloud interactions.

\section{Hemispheric Contrast}

Most anthropogenic aerosol sources are located in the Northern Hemisphere. The short lifetime of the aerosol confines their effects also mostly to the Northern Hemisphere, in which aerosol-cloud interaction effects are expected to be much larger [78]. Anthropogenic $\mathrm{SO}_{2}$ is, to a dominating extent, emitted in the Northern Hemisphere, with 98 vs. $6 \mathrm{Tg}$ $S$ year ${ }^{-1}$ [79]. Moderate Resolution Imaging Spectroradiometer (MODIS) retrievals of the aerosol optical depth (AOD) show a distinct hemispheric contrast even over ocean, with an AOD of about $50 \%$ larger in the Northern Hemisphere [80]. For MODIS-retrieved fine-mode AOD, the difference over the oceans is 0.094 vs. 0.061 [81]. Hemispheric differences were also found for droplet sizes. Annual (1987 and 1988) average droplet effective radii from the Advanced Very High Resolution Radiometer (AVHRR) on board the NOAA-9 and NOAA-10 satellites show a contrast of $11.0 \mu \mathrm{m}$ in the Northern Hemisphere vs. $11.7 \mu \mathrm{m}$ in the Southern Hemisphere [82]. MODIS shows a difference of 12.4 vs. $13.0 \mu \mathrm{m}$ in droplet effective radii [81]. However, for the optical depth of liquid water clouds, the results are inconclusive: AVHRR shows a cloud optical depth of 6.6 in the Northern Hemisphere and 7.4 in the Southern Hemisphere [82]. This result was found both over land and ocean. Cloud optical depth from MODIS, in turn, was found to be slightly larger in the Northern Hemisphere over ocean at 12.6 vs. 12.1 in the Northern Hemisphere vs. the Southern Hemisphere. The contrast, however, was much smaller than predicted by a chemistry transport model [81]. Cloud albedo is also larger in the Southern Hemisphere than in the Northern Hemisphere for mid to high latitudes [79].

These results imply that the clouds between the hemispheres differ not only due to the differences in aerosol but also due to differences in the large-scale circulation and in the land-ocean distribution. The differences in the aerosol are not completely attributable to anthropogenic activities, since some of the major deserts are in the Northern Hemisphere and 
biomass burning differences are also not solely due to anthropogenic combustion. The fact that cloud albedo is not significantly larger, or even smaller, in the Northern Hemisphere is an indication that the aerosol is not a first-order factor for cloud properties [79]. The hemispheric difference in aerosol emissions and the observed warming in both hemispheres consequently also allows to infer an upper bound in the aerosol forcing [83•].

In summary, the hemispheric contrast is useful because it allows to leverage many observations. However, the convolution of many different effects hampers the analysis of individual effects. As such, only broad constraints on the aerosolcloud interactions are possible.

\section{Trace Gases}

The possibilities to observe aerosols from satellites or groundbased remote sensing in cloudy regions are limited. In contrast, trace gases may be observed also in cloudy skies. Also, aerosols are emitted from both natural and anthropogenic sources so that a clear identification of the anthropogenic component is difficult. In turn, some trace gases such as $\mathrm{CO}$ are clearly attributable to combustion. While this includes natural fires, in many situations, it can be attributed to anthropogenic activity. $\mathrm{CO}$ and aerosol concentrations are tightly related near the source regions $[84,85]$ as long as the concentrations are more determined by the source strength than by the lifetime. $\mathrm{CO}$ lifetime is longer than the aerosol lifetime, since $\mathrm{CO}$ is less efficiently scavenged and deposited compared to the aerosol. The influence of oxidants on both, $\mathrm{CO}$ and aerosol, complicates the relationship [86]. Despite these limitations, relationships between $\mathrm{CO}$ concentrations and cloud properties have been found in observations that are promising for process analysis. Elevated concentrations of $\mathrm{CO}$ have been demonstrated to coincide with increased cloud droplet number concentration and decreased cloud droplet effective radii as well as with increased cloud optical depth [87].

A related approach is to combine observations with chemistry transport modelling in weather forecast mode. The model results allow the identification of air masses subject to pollution, and observations of cloud and radiation in polluted conditions can be compared to less polluted or unpolluted ones [88-90].

In conclusion, retrievals of trace gases from satellites may help to identify anthropogenic pollution. However, ambiguity remains especially due to the differences in lifetime and sinks. Also, models may help to identify anthropogenic aerosol. A challenge in either case is to distinguish the effect due the anthropogenic emissions from other perturbations that are convolved with the pollution such as different origins and histories of air masses.

\section{Weekly Cycles}

An unambiguous 7-day cycle is hardly attributable to natural variability. Trace gases like $\mathrm{NO}_{2}$ show distinct minima on Sundays over North America and Europe, on Fridays over the Middle East and on Saturdays over Israel and no clear minimum over China [91]. Early studies of the weekly cycle were intended to demonstrate a greenhouse effect and found cooler temperatures on weekends over the Northern Hemisphere [92]. Weekly cycles in precipitation have been found with a minimum coincident with the pollutant minimum [93] or pollutant maximum [94]. To date, weekly cycles for many meteorological parameters are inconclusive and differ among the different studies [95•]. The attempt to detect and attribute weekly cycles in cloud properties such as cloud fraction and liquid water path, radiation fluxes or meteorological parameters such as surface temperature to anthropogenic aerosols fails except for the basic parameters such as aerosol optical depth and cloud droplet number concentration [96]. A problem is the challenge of assessing statistical significance: The occurrence of a single maximum and minimum each, among just seven instances, is rather likely, and high confidence levels are required [95•].

The analysis of weekly cycles, nevertheless, is a particularly promising avenue for a constraint and quantification of the effects of anthropogenic aerosols. Combination of modelling and observations may allow for a clear attribution of weekly cycles in particular quantities to anthropogenic aerosol. The relative importance of the weekly cycle in emission with respect to total emissions may allow an estimation of the anthropogenic radiative forcing, should a weekly cycle in radiation be identifiable, by scaling the weekly amplitude to the total emission strength.

\section{Trends}

Anthropogenic aerosol emissions increased substantially since pre-industrial times and have subsequently decreased in some regions such as Europe in the past few decades [97]. At the same time, solar radiation at the surface has changed by $-7 \mathrm{Wm}^{-2}$ globally between 1961 and 1990 [98]. Over North America, a larger decreasing trend was found for cloudy compared to clear skies [98]. In turn, since a few decades, the trends are reversed in many regions from this 'dimming', leading to a 'brightening', or increases in surface solar radiation both in clear and cloudy skies [99]. This increasing trend coincides, over Europe, with a decline of fog and haze and an increase in visibility [100]. Particularly strong increasing trends in aerosol emissions occurred over China. These coincided with decreases in visibility and increases in aerosol optical depth, but also in meteorological parameters [101]. Climate models show that the trend in all-sky surface solar 
radiation due to aerosol emission reductions is correlated to the effective radiative forcing by anthropogenic aerosol, allowing for a constraint on the simulated aerosol forcing [102•]. Trends in other meteorological quantities may be related to aerosol effects as far as the models show a clear link between observable trends in such quantities and anthropogenic aerosol emissions. In this regard, trends in the diurnal temperature range [103], monsoon precipitation [28, 104, 105], Sahel drought [106] or the North Atlantic oscillation [107] have been attributed to anthropogenic aerosol emissions.

Besides long-term trends, there are occasionally also abrupt changes in anthropogenic emissions. In the period 11-14 September 2001, all commercial air traffic was banned over North America. This has been exploited to detect a change in the diurnal temperature range possibly attributable to the lack in contrails $[108,109]$. During the Olympic Games in Beijing, emission controls led to substantial transient reductions in air pollution $[110,111]$. Fireworks lead to occasional substantial enhancements in anthropogenic pollution $[112,113]$. Such short, singular events are, however, difficult to exploit for a systematic process analysis and are not suitable for a forcing assessment.

Trends are thus, despite the ambiguity, especially valuable for a constraint on the aerosol forcing and for studies attributing observed climate change aspects to aerosols. They are not as suited for an improved process understanding concerning the interaction of aerosols with cloud microphysical and microdynamical processes.

\section{Conclusions}

The large uncertainty in anthropogenic aerosol forcing that hampers quantitative understanding and prediction of current climate change urgently needs to be reduced. Ideal for this would be an estimate from observations, or else a constraint of the simulated forcing, based on observations. So far, process-oriented metrics (statistical relationships between relevant quantities such as between aerosol and cloud droplet concentration, cloud droplet concentration, albedo, etc.) were used for this goal. However, since a multitude of fast adjustments is acting and effects may be buffered, the actual observation of the perturbation of clouds and the radiation budget unequivocally attributable to anthropogenic aerosol is highly desirable. The challenge is due to the large natural variability in clouds and their strong impact on radiation. Even in the global annual mean, the cloud radiative effect is about $-50 \mathrm{Wm}^{-2}$ [114], while the aerosol forcing is of the order of $2 \%$ of this.

Six approaches to this end are identified and discussed in this review. All of them are useful, but as summarised in Table 1, two of them (ship tracks and intentional weather
Table 1 Methods to observe the anthropogenic aerosol effect and possible applications for a radiative forcing estimate or for improved process-level understanding of the effect of anthropogenic aerosol on clouds and radiation

\begin{tabular}{lll}
\hline Method & Forcing estimate & Process understanding \\
\hline Weather modification & - & $\mathrm{x}$ \\
Ship tracks & - & $\mathrm{x}$ \\
Hemispheric contrast & 1 & - \\
Trace gases & 1 & 1 \\
Weekly cycles & $\mathrm{x}$ & 1 \\
Trends & $\mathrm{x}$ & 1
\end{tabular}

'-' stands for little use, 'l' limited applicability, and ' $\mathrm{x}$ ' for promising applicability

modification) are only for an improved process understanding, not an actual estimate of, or constraint on, the forcing. This is due to the small scales they are applicable to. The analysis of the hemispheric contrast is difficult since perturbations clearly attributable to aerosols cannot be disentangled from other influences. Nevertheless, important constraints can be derived from hemispheric differences. Using trace gases as markers of anthropogenic pollution, or using modelling to identify pollution, is useful for both, process analyses and forcing assessment, but only in a limited scope close to source regions. The assessment of weekly cycles and trends emerges as the most powerful avenue to infer relevant, quantitative information about the aerosol forcing, but also to a more limited extent, process assessment.

Obtaining a significant signal-to-noise ratio for both, trends and weekly cycles, requires long time series of consistent measurements. Thus, the extension of current observational records, both ground based and space borne, is a prerequisite for increasingly convincing assessments.

Most useful are studies that combine the observational assessments with model sensitivity studies in order to clearly attribute effects in observations to anthropogenic emissions and particular processes by which these affect clouds and the radiation budget. This requires models that realistically represent the relevant processes and their interactions. A successful forcing estimate or constraint thus calls for an iterative approach: improved process understanding from observations analysis (e.g. ship track analysis) and subsequent model improvement, and forcing estimates and constraints from observations in combination with model sensitivity studies, best from weekly cycle or trend analysis.

Acknowledgments Funding by the European Research Council, Starting Grant QUAERERE, grant agreement no. 306284, is acknowledged. Some thoughts stem from discussions within the Aerosols, Clouds, Precipitation and Climate (ACPC) initiative from iLEAPS and GEWEX. I thank the NASA Goddard Institute for Space Sciences (GISS) for hospitality during my research semester when writing this review. I acknowledge the very useful help by the three anonymous reviewers. 


\section{Compliance with Ethical Standards}

Conflict of Interest I declare that there is no conflict of interest.

Open Access This article is distributed under the terms of the Creative Commons Attribution 4.0 International License (http:// creativecommons.org/licenses/by/4.0/), which permits unrestricted use, distribution, and reproduction in any medium, provided you give appropriate credit to the original author(s) and the source, provide a link to the Creative Commons license, and indicate if changes were made.

\section{References}

Papers of particular interest, published recently, have been highlighted as:

- Of importance

1. Boucher O, Randall D, Artaxo P, Bretherton C, Feingold G, Forster P, et al. Clouds and aerosols. In: Stocker TF, Qin D, Plattner GK, Tignor M, Allen SK, Boschung J, et al., editors. Climate change 2013: the physical science basis. Contribution of Working Group I to the Fifth Assessment Report of the Intergovernmental Panel on Climate Change. Cambridge, UK, and New York, NY, USA: Cambridge University Press; 2013. pp. 571-658.

2. Kay JE, Wood R. Timescale analysis of aerosol sensitivity during homogeneous freezing and implications for upper tropospheric water vapor budgets. Geophys Res Lett. 2008;35:L10809.

3. Twomey S. Pollution and the planetary albedo. Atmos Environ. 1974;8:1251-8.

4. Kärcher B, Lohmann U. A parameterization of cirrus cloud formation: heterogeneous freezing. J Geophys Res. 2003;108:4402.

5. Albrecht B. Aerosols, cloud microphysics, and fractional cloudiness. Science. 1989;245:1227-30.

6. Xue H, Feingold G. Large-eddy simulations of trade wind cumuli: investigation of aerosol indirect effects. J Atmos Sci. 2006;63:1605-22.

7. Wood R. Cancellation of aerosol indirect effects in marine stratocumulus through cloud thinning. J Atmos Sci. 2007;64:2657-69.

8. Sandu I, Brenguier JL, Geoffroy O, Thouron O, Masson V. Aerosols impacts on the diurnal cycle of marine stratocumulus. $\mathrm{J}$ Atmos Sci. 2008;65:2705-18.

9. Seifert A, Heus T, Pincus R, Stevens B. Large-eddy simulation of the transient and near-equilibrium behavior of precipitating shallow convection. J Adv Model Earth Syst. 2015. doi:10.1002/ 2015MS000489.

10. Pincus R, Baker MB. Effect of precipitation on the albedo susceptibility of clouds in the marine boundary layer. Nature. 1994;372: 250-2.

11. Fan J, Leung LR, Rosenfeld D, Chen Q, Li Z, Zhang J, et al. Microphysical effects determine macrophysical response for aerosol impacts on deep convective clouds. Proc Natl Acad Sci U S A. 2013;110:E4581-90.

12. Savic-Jovcic V, Stevens B. The structure and mesoscale organization of precipitating stratocumulus. J Atmos Sci. 2008;65: 1587-605.

13. Small JD, Chuang PY, Feingold G, Jiang H. Can aerosols decrease cloud lifetime? Geophys Res Lett. 2009;36:L16806.
14. Ackerman AS, Kirkpatrick MP, Stevens DE, Toon OB. The impact of humidity above stratiform clouds on indirect aerosol climate forcing. Nature. 2004;432:1014-7.

15. Lohmann U. A glaciation indirect aerosol effect caused by soot aerosols. Geophys Res Lett. 2002;29:1052-6.

16. Storelvmo T, Kristjánsson JE, Lohmann U, Iversen T, Kirkevåg A, Seland O. Modeling of the Wegener-Bergeron-Findeisen process-implications for aerosol indirect effects. Environ Res Lett. 2008;3:045001.

17. Storelvmo T, Kristjánsson JE, Lohmann U, Iversen T, Kirkevåg A, Seland O. Corrigendum: modeling of the Wegener-BergeronFindeisen process - implications for aerosol indirect effects. Environ Res Lett. 2010;5:019801.

18. Ackerman AS, Toon OB, Stephens DE, Heymsfield AJ, Ramanathan V, Welton EJ. Reduction of tropical cloudiness by soot. Science. 2000;288:1042-7.

19. Koch D, Del Genio AD. Black carbon semi-direct effects on cloud cover: review and synthesis. Atmos Chem Phys. 2010;10:7685-96.

20. Sakaeda N, Wood R, Rasch PJ. Direct and semidirect aerosol effects of Southern African biomass burning aerosol. J Geophys Res. 2011;116:D12205.

21. Wilcox EM. Direct and semi-direct radiative forcing of smoke aerosols over clouds. Atmos Chem Phys. 2012;12:139-49.

22. Stevens B, Feingold G. Untangling aerosol effects on clouds and precipitation in a buffered system. Nature. 2009;461:607-13.

23. Quaas J, Bony S, Collins WD, Donner L, Illingworth AJ, Jones A, et al. In: Current understanding and quantification of clouds in the changing climate system and strategies for reducing critical uncertainties. MIT, Cambridge, ISBN 9780262012874; 2009. pp. 557-573.

24. Lohmann U, Rotstayn L, Storelvmo T, Jones A, Menon S, Quaas $\mathrm{J}$, et al. Total aerosol effect: forcing or radiative flux perturbation. Atmos Chem Phys. 2010;10:3235-46.

25. Gregory J, Webb M. Tropospheric adjustment induces a cloud component in CO2 forcing. J Clim. 2008;21:58-71.

26. Zelinka MD, Andrews T, Forster PM, Taylor KE. Quantifying components of aerosol-cloud-radiation interactions in climate models. J Geophys Res. 2014;119:7599-615.

27. Sherwood SC, Bony S, Boucher O, Bretherton C, Forster PM, Gregory JM, et al. Adjustments in the forcing-feedback framework for understanding climate change. Bull Am Meteorol Soc. 2015;96:217-28.

28. Cherian R, Venkataraman C, Quaas J, Ramachandran S. GCM simulations of aerosol extinction, heating and effects on precipitation over India. J Geophys Res. 2013;118:2938-55.

29. Twomey S, Warner J. Comparison of measurements of cloud droplets and cloud nuclei. J Atmos Sci. 1967;24:702-3.

30. Feingold G, Eberhard WL, Veron DE, Previdi M. First measurements of the Twomey indirect effect using ground-based remote sensors. Geophys Res Lett. 2003;30:1287.

31. Werner F, Ditas F, Siebert H, Simmel M, Wehner B, Pilewskie P, et al. Twomey effect observed from collocated microphysical and remote sensing measurements over shallow cumulus. J Geophys Res. 2014;119:1534-45.

32. Lohmann U, Lesins G. Stronger constraints on the anthropogenic indirect aerosol effect. Science. 2002;298:1012-5.

33. Sekiguchi M, Nakajima T, Suzuki K, Kawamoto K, Higurashi A, Rosenfeld D, et al. A study of the direct and indirect effects of aerosols using global satellite data sets of aerosol and cloud parameters. J Geophys Res. 2003;108:4699.

34. Quaas J, Boucher O, Bréon FM. Aerosol indirect effects in POLDER satellite data and in the Laboratoire de Météorologie Dynamique-Zoom (LMDZ) general circulation model. J Geophys Res. 2004;109:D08205. 
35. Quaas J, Boucher O. Constraining the first aerosol indirect radiative forcing in the LMDZ GCM using POLDER and MODIS satellite data. Geophys Res Lett. 2005;32(L17814).

36. Quaas J, Boucher O, Lohmann U. Constraining the total aerosol indirect effect in the LMDZ and ECHAM4 GCMs using MODIS satellite data. Atmos Chem Phys. 2006;6:947-55.

37. Suzuki K, Golaz JC, Stephens GL. Evaluating cloud tuning in a climate model with satellite observations. Geophys Res Lett. 2013;40:4464-8.

38. Quaas J, Boucher O, Bellouin N, Kinne S. Satellite-based estimate of the direct and indirect aerosol climate forcing. J Geophys Res. 2008;113(D05204).

39. Quaas J, Ming Y, Menon S, Takemura T, Wang M, Penner J, et al. Aerosol indirect effects - general circulation model intercomparison and evaluation with satellite data. Atmos Chem Phys. 2009;9: 8697-717.

40. Chen YC, Christensen MW, Stephens GL, Seinfeld JH. Satellitebased estimate of global aerosol-cloud radiative forcing by marine warm clouds. Nat Geosci. 2014;7:643-6.

41. Bellouin N, Jones A, Haywood J, Christopher SA. Updated estimate of aerosol direct radiative forcing from satellite observations and comparison against the Hadley Centre climate model. J Geophys Res. 2008;113:D10205.

42. Carslaw KS, Lee LA, Reddington CL, Pringle KJ, Rap A, Forster PM, et al. Large contribution of natural aerosols to uncertainty in indirect forcing. Nature. 2013;503:67-71.

43. Schaefer VJ. The production of ice crystals in a cloud of supercooled water droplets. Science. 1946;104:457-9.

44. Simpson J, Simpson RH, Andrews DA, Eaton MA. Experimental cumulus dynamics. Rev Geophys. 1965;3:387-431.

45. Langmuir I. The production of rain by a chain reaction in cumulus clouds at temperatures above freezing. J Meteorol. 1948;5:175-92.

46. Bowen EG. A new method of stimulating convective clouds to produce rain and hail. QJR Meteorol Soc. 1952;78:37-45.

47. Biswas KR, Kapoor RK, Kanuga KK, Ramana Murty BV. Cloud seeding experiment using common salt. J Appl Meteorol. 1967;6: 914-23.

48. National Research Council. Critical issues in weather modification research. Washington D.C., USA: The National Academies Press; 2003. ISBN 978-0-309-09053-7.

49. Levin Z, Halfon N, Alpert P. Reassessment of rain enhancement experiments and operations in Israel including synoptic considerations. Atmos Res. 2010;97:513-25.

50. Ghate VP, Albrecht BA, Kollias P, Jonsson HH, Breed DW. Cloud seeding as a technique for studying aerosol-cloud interactions in marine stratocumulus. Geophys Res Lett. 2007;34:L14807.

51. Russell LM, Sorooshian A, Seinfeld JH, Albrecht BA, Nenes A, Ahlm L, et al. Eastern pacific emitted aerosol cloud experiment. Bull Am Meteorol Soc. 2013;94:709-29.

52. Latham J, Bower K, Choularton T, Coe H, Connolly P, Cooper G, et al. Marine cloud brightening. Philos Transact A Math Phys Eng Sci. 2012;370:4217-62.

53. Wood R, Ackerman TP. Defining success and limits of field experiments to test geoengineering by marine cloud brightening. Clim Chang. 2013;121:459-72.

54. Conover JH. Anomalous cloud lines. J Atmos Sci. 1966;23: 778-85.

55. Coakley Jr JA, Durkee PA, Nielsen K, Taylor JP, Platnick S, Albrecht BA, et al. The appearance and disappearance of ship tracks on large spatial scales. J Atmos Sci. 2000;57:2765-78.

56. Durkee PA, Chartier RE, Brown A, Trehubenko EJ, Rogerson SD, Skupniewicz C, et al. Composite ship track characteristics. J Atmos Sci. 2000;57:2542-53.
57. Noone KJ, Öström E, Ferek RJ, Garrett T, Hobbs PV, Johnson $\mathrm{DW}$, et al. A case study of ships forming and not forming tracks in moderately polluted clouds. J Atmos Sci. 2000;57:2729-47.

58. Coakley Jr JA, Bernstein RL, Durkee PA. Effect of ship-stack effluents on cloud reflectivity. Science. 1987;237:1020-2022.

59. Wang H, Feingold G. Modeling mesoscale cellular structures and drizzle in marine stratocumulus. Part II: the microphysics and dynamics of the boundary region between open and closed cells. J Atmos Sci. 2009;66:3257-75.

60. Goren T, Rosenfeld D. Satellite observations of ship emission induced transitions from broken to closed cell marine stratocumulus over large areas. J Geophys Res. 2012;117:D17206.

61. Goren T, Rosenfeld D. Decomposing aerosol cloud radiative effects into cloud cover, liquid water path and Twomey components in marine stratocumulus. Atmos Res. 2014;138:378-93.

62. Lauer A, Eyring V, Hendricks J, Jöckel P, Lohmann U. Global model simulations of the impact of ocean-going ships on aerosols, clouds, and the radiation budget. Atmos Chem Phys. 2007;7:5061-79.

63. Peters K, Quaas J, Stier P, Graß1 H. Processes limiting the emergence of detectable aerosol indirect effects on tropical warm clouds in global aerosol-climate model and satellite data. Tellus B. 2014;66:24054.

64. Campmany E, Grainger RG, Dean SM, Sayer AM. Automatic detection of ship tracks in ATSR-2 satellite imagery. Atmos Chem Phys. 2009;9:1899-905.

65. Schreier M, Mannstein H, Eyring V, Bovensmann H. Global ship track distribution and radiative forcing from 1 year of AATSR data. Geophys Res Lett. 2007;34:L17814.

66. Schreier M, Joxe L, Eyring V, Bovensmann H, Burrows JP. Ship track characteristics derived from geostationary satellite observations on the west coast of southern Africa. Atmos Res. 2010;95: 32-9.

67. Peters K, Quaas J, Graß1 H. A search for large-scale effects of ship emissions on clouds and radiation in satellite data. J Geophys Res. 2011;116:D24205.

68. Capaldo K, Corbett JJ, Kasibhatla P, Fischbeck P, Pandis SN Effects of ship emissions on sulphur cycling and radiative climate forcing over the ocean. Nature. 1999;400:743-6.

69. Ackerman AS, Toon OB, Taylor JP, Johnson DW, Hobbs PV, Ferek RJ. Effects of aerosols on cloud albedo: evaluation of Twomey's parameterization of cloud susceptibility using measurements of ship tracks. J Atmos Sci. 2000;57:2684-95.

70. Chen YC, Christensen MW, Xue L, Sorooshian A, Stephens GL, Rasmussen RM, et al. Occurrence of lower cloud albedo in ship tracks. Atmos Chem Phys. 2012;12:8223-35.

71. Christensen MW, Coakley Jr JA, Tahnk WR. Morning-toafternoon evolution of marine stratus polluted by underlying ships: implications for the relative lifetimes of polluted and unpolluted clouds. J Atmos Sci. 2009;66:2097-106.

72. Christensen MW, Suzuki K, Zambri B, Stephens GL. Ship track observations of a reduced shortwave aerosol indirect effect in mixed-phase clouds. Geophys Res Lett. 2014;41:6970-7. This study is an excellent example on how the careful, statistical analysis of ship tracks is useful to assess processes of aerosolcloud interactions.

73. Coakley Jr JA, Walsh CD. Limits to the aerosol indirect radiative effect derived from observations of ship tracks. J Atmos Sci. 2002;59:668-80.

74. Christensen MW, Stephens GL. Microphysical and macrophysical responses of marine stratocumulus polluted by underlying ships: evidence of cloud deepening. J Geophys Res. 2011;116:D03201.

75. Boucher O. Air traffic may increase cirrus cloudiness. Nature 1999;397:30-1.

76. Burkhardt U, Kärcher B. Global radiative forcing from contrail cirrus. Nat Clim Chang. 2011;1:54-8. 
77. Hendricks J, Kärcher B, Lohmann U, Ponater M. Do aircraft black carbon emissions affect cirrus clouds on the global scale? Geophys Res Lett. 2005;32:L12814.

78. Ming Y, Ramaswamy V. A model investigation of aerosolinduced changes in tropical circulation. J Clim. 2011;24: 5125-33.

79. Schwartz SE. Are global cloud albedo and climate controlled by marine phytoplankton? Nature. 1988;336:441-5.

80. Kishcha P, Starobinets B, Kalashnikova O, Long CN, Alpert P. Variations of meridional aerosol distribution and solar dimming. J Geophys Res. 2009;114:D00D14.

81. Feng Y, Ramanathan V. Investigation of aerosol-cloud interactions using a chemical transport model constrained by satellite observations. Tellus. 2010;62B:69-86.

82. Han Q, Rossow WB, Lacis AA. Near-global survey of effective droplet radii in liquid water clouds using ISCCP data. J Clim. 1994; 7:465-97.

83. Stevens B. Rethinking the lower bound on aerosol radiative forcing. J Clim. 2015;28:4794-819. This study exploits the hemispheric contrast to infer constraints on the magnitude of the anthropogenic aerosol radiative forcing.

84. Longley ID, Inglis DWF, Gallagher MW, Williams PI, Allan JD, $\mathrm{Coe} \mathrm{H}$. Using NOx and $\mathrm{CO}$ monitoring data to indicate fine aerosol number concentrations and emission factors in three UK conurbations. Atmos Environ. 2005;39:5157-69.

85. Bian H, Chin M, Kawa SR, Yu H, Diehl T, Kucsera T. Multiscale carbon monoxide and aerosol correlations from satellite measurements and the GOCART model: implication for emissions and atmospheric evolution. J Geophys Res. 2010;115, D07302.

86. Edwards DP, Emmons LK, Hauglustaine DA, Chu DA, Gille JC, Kaufman YJ, et al. Observations of carbon monoxide and aerosols from the Terra satellite: Northern Hemisphere variability. J Geophys Res. 2004;109:D24202.

87. Avey L, Garrett TJ, Stohl A. Evaluation of the aerosol indirect effect using satellite, tracer transport model, and aircraft data from the International Consortium for Atmospheric Research on Transport and Transformation. J Geophys Res. 2007;112:D10S33.

88. Chameides WL, Luo C, Saylor R, Streets D, Huang Y, Bergin M, et al. Correlation between model-calculated anthropogenic aerosols and satellite-derived cloud optical depths: indication of indirect effect? J Geophys Res. 2002;107:4085.

89. Schwartz SE, Harshvardhan, Benkovitz CM. Influence of anthropogenic aerosol on cloud optical depth and albedo shown by satellite measurements and chemical transport modeling. Proc Natl Acad Sci U S A. 2002;99:1784-9.

90. Kawamoto K, Hayasaka T, Uno I, Ohara T. A correlative study on the relationship between modeled anthropogenic aerosol concentration and satellite-observed cloud properties over east Asia. J Geophys Res. 2006;111:D19201.

91. Beirle S, Platt U, Wenig M, Wagner T. Weekly cycle of NO2 by GOME measurements: a signature of anthropogenic sources. Atmos Chem Phys. 2003;3:2225-32.

92. Gordon AH. Weekdays warmer than weekends? Nature. 1994;367:324-5.

93. Cerveny RS, Balling Jr RC. Weekly cycles of air pollutants, precipitation and tropical cyclones in the coastal NW Atlantic region. Nature. 1998;394:561-3.

94. Bäumer D, Vogel B. An unexpected pattern of distinct weekly periodicities in climatological variables in Germany. Geophys Res Lett. 2007;34:L03819.

95. Sanchez-Lorenzo A, Laux P, Hendricks-Franssen HJ, Georgoulias AK, Calbó J, Vogl S, et al. Assessing large-scale weekly cycles in meteorological variables: a review. Atmos Chem Phys. 2012;12:
5755-71. This article provides a comprehensive review about weekly cycles and the challenges in clearly identifying these as well as in exploiting the information to gain knowledge about aerosol effects.

96. Quaas J, Boucher O, Jones A, Weedon GP, Kieser J, Joos H. Exploiting the weekly cycle as observed over Europe to analyse aerosol indirect effects in two climate models. Atmos Chem Phys. 2009;9:8493-501.

97. Vestreng V, Myhre G, Fagerli H, Reis S, Tarrasón L. Twenty-five years of continuous sulphur dioxide emission reduction in Europe. Atmos Chem Phys. 2007;7:3663-81.

98. Liepert BG. Observed reductions in surface solar radiation in the United States and worldwide from 1961 to 1990 . Geophys Res Lett. 2002;29(10). doi:10.1029/2002GL014913.

99. Wild M, Gilgen H, Roesch A, Ohmura A, Long CN, Dutton EG, et al. From dimming to brightening: decadal changes in solar radiation at Earth's surface. Science. 2005;308:847-50.

100. Vautard R, Yiou P, van Oldenborgh GJ. Decline of fog, mist and haze in Europe over the past 30 years. Nat Geosci. 2009;2:115-9.

101. Yang X, Yao Z, Li Z, Fan T. Heavy air pollution suppresses summer thunderstorms in Central China. J Atmos Sol-Terr Phys. 2013;95-96:28-40.

102. Cherian R, Quaas J, Salzmann M, Wild M. Pollution trends over Europe constrain global aerosol forcing as simulated by climate models. Geophys Res Lett. 2014;41:2176-81. This article is a prime example on how to exploit analysis-observed trends in order to constrain the aerosol radiative forcing.

103. Quaas J, Boucher O, Dufresne JL, Le Treut H. Impacts of greenhouse gases and aerosol direct and indirect effects on clouds and radiation in atmospheric GCM simulations of the 1930-1989 period. Clim Dyn. 2004;23:779-89.

104. Bollasina M, Ming Y, Ramaswamy V. Anthropogenic aerosols and the weakening of the South Asian summer monsoon. Science. 2011;334:502-5.

105. Salzmann M, Weser H, Cherian R. Robust response of Asian summer monsoon to anthropogenic aerosols in CMIP5 models. J Geophys Res. 2014;119:11321-37.

106. Rotstayn LD, Lohmann U. Tropical rainfall trends and the indirect aerosol effect. J Clim. 2002;15:2103-16.

107. Booth BBB, Dunstone NJ, Halloran PR, Andrews T, Bellouin N. Aerosols implicated as a prime driver of twentieth-century North Atlantic climate variability. Nature. 2012;484:228-32.

108. Travis DJ, Carleton AM, Lauritsen RG. Contrails reduce daily temperature range. Nature. 2002;418:601.

109. Travis DJ, Carleton AM, Lauritsen RG. Regional variations in U.S. diurnal temperature range for the 11-14 September 2001 aircraft groundings: evidence of jet contrail influence on climate. J Clim. 2004;17:1123-34.

110. Gao Y, Liu X, Zhao C, Zhang M. Emission controls versus meteorological conditions in determining aerosol concentrations in Beijing during the 2008 Olympic Games. Atmos Chem Phys. 2011;11:12437-51.

111. Cermak J, Knutti R. Beijing Olympics as an aerosol field experiment. Geophys Res Lett. 2009;36:L10806.

112. Gong DY, Wang W, Qian Y, Bai W, Guo Y, Mao R. Observed holiday aerosol reduction and temperature cooling over East Asia. J Geophys Res. 2014;119:6306-24.

113. Saha U, Talukdar S, Jana S, Maitra A. Effects of air pollution on meteorological parameters during Deepawali festival over an Indian urban metropolis. Atmos Environ. 2014;98:530-9.

114. Stephens GL, Li J, Wild M, Clayson CA, Loeb N, Kato S, et al. An update on Earth's energy balance in light of the latest global observations. Nat Geosci. 2012;5:691-6. 